УДК 78.03:001.4

\section{Цитування:}

Kapliyenko-Iliuk Y. Polystylistics: problems of definition and terminology [Полістилістика: проблеми визначення та термінології]. Вісник Національної академії керівних кадрів культури $і$ мистеитв : наук. журнал. № 2. Київ : ІДЕЯ ПРИНТ, 2020. С. 192-197.

Kapliyenko-Iliuk Y. (2020). Polystylistics: problems of definition and terminology. National Academy of Culture and Arts Management Herald: Science journal, 2, 192-197 [in Ukrainian].

\author{
Kapliyenko-Iliuk Yuliya, \\ Ph.D. in Arts, associate professor, \\ doctoral student of the Odessa National \\ A. V. Nezhdanova Academy of Music \\ ORCID: https://orcid.org/0000-0002-6114-9680 \\ yuliyakaplienko@gmail.com
}

\title{
POLYSTYLISTICS: PROBLEMS OF DEFINITION AND TERMINOLOGY
}

The purpose of the article is to reveal the essence of the category of polystylistics on the basis of musicological research and to characterize the related concepts that correspond to the manifestations of stylistic interactions. The methodology is determined by the works of musicological and cultural direction, where attention is paid to the problems of style, polystylistics, encyclopedic sources, which reveal the essence of the concept of polystylistics and dissertation studies on the issues of polystylistics in music and art culture. The scientific novelty lies in the scientific understanding of polystylistics in music; in the systematization of the results of studies of the process of stylistic interactions; in explaining the principles of defining polystylistics and the related concepts. Conclusions. Polystylistics as a phenomenon of contemporary art and as a category of musicology, from its origin to the present time, has received new scientific interpretations. The combination of styles, which became the basis for the modern trend postmodernism, reveals a large number of views on this phenomenon, which has led to both varieties of manifestations and a variety of interpretations of the term. The first theoretical substantiation of the concept of polystylistics was given in the report "Polystylistic Tendencies in Contemporary Music" by A. Schnittke. The definition of "polystylistics," which emerged in A. Schnittke's research, was formed into a more stable form in the definitions of the following generations of art critics and contemporaries, which brought this phenomenon to the level of the musicological category. A number of the related concepts are involved in the scientific space; they reveal style interactions in different ways, but to a certain extent correspond to the category of polystylistics. The work which was done to arrange the definitions of polystylistics and diverse terminology will be able to enrich scientists' views on the problems of polystylistics and reveal the essence of the phenomenon from different points of view.

Key words: style, polystylistics, stylistic polyphony, stylistic modeling, intercultural interactions.

Капліснко-Ілюк Юлія Володимирівна, кандидат мистецтвознавства, доцент, докторант Одеської національноі музичної академї ім. А. В. Нежданової

Полістилістика: проблеми визначення та термінології

Мета статті - розкрити сутність категорії полістилістики на основі музикознавчих досліджень та охарактеризувати суміжні поняття, які відповідають проявам стильових взаємодій. Методологія визначається працями музикознавчого та культурологічного спрямування, де приділяється увага проблемам стилю, полістилістики, енциклопедичними джерелами, у яких розкривається сутність поняття полістилістики, дисертаційними дослідженнями, присвяченими питанням полістилістики у музичній та художній культурі. Наукова новизна полягає у науковому осмисленні полістилістики в музиці; у систематизації результатів досліджень процесу стильових взаємодій; у з'ясуванні принципів визначення полістилістики та суміжних понять. Висновки. Полістилістика як явище сучасного мистецтва та як категорія музикознавства, починаючи від свого зародження до нашого часу, отримує нові наукові інтерпретації. Поєднання стилів, що стало основою сучасного напрямку - постмодернізму, виявляс велику кількість поглядів на дане явище, що спричинило як багатоманітність прояву, так і різнохарактерність тлумачення терміну. Перше теоретичне обгрунтування поняття полістилістики отримало у доповіді "Полістилістичні тенденції в сучасній музиці" А. Шнітке. Визначення поняття "полістилістика", що намітилось у дослідженні А. Шнітке, сформувалось у стійкішу форму в дефініціях наступних поколінь мистецтвознавців та сучасників, що вивело дане явище на рівень музикознавчої категорії. У науковий простір залучається ряд суміжних понять, які по-різному розкривають стильові взаємодії, проте певною мірою відповідають категорії полістилістики. Здійснена робота над упорядкуванням дефініцій полістилістики та розмаїтої термінології зможе збагатити погляди науковців на проблеми полістилістики та розкрити сутність явища 3 різних позицій.

Ключові слова: стиль, полістилістика, стилістична поліфонія, стильове моделювання, міжкультурні взаємодії.

CKapliyenko-Iliuk Yu., 2020 


\section{Вісник Національної академії керівних кадрів культури і мистецтв № 2'2о20}

Каплиенко-Илюк Юлия Владимировна, кандидат искусствоведения, доцент, докторант Одесской национальной музыкальной академии им. А. В. Неждановой

Полистилистика: проблемы определения и терминологии

Цель статьи - раскрыть сущность категории полистилистики на основе музыковедческих исследований и охарактеризовать смежные понятия, соответствующие проявлениям стилевых взаимодействий. Методология определяется трудами музыковедческого и культурологического направления, где уделяется внимание проблемам стиля, полистилистики, энциклопедическими источниками, в которых раскрывается сущность понятия полистилистики, диссертационными исследованиями, посвященными вопросам полистилистики в музыкальной и художественной культуре. Научная новизна заключается в научном осмыслении полистилистики в музыке; в систематизации результатов исследований процесса стилевых взаимодействий; в выяснении принципов определения полистилистики и смежных понятий. Выводы. Полистилистика как явление современного искусства и как категория музыковедения, начиная от своего зарождения до наших дней, получает новые научные интерпретации. Сочетание стилей, которое стало основой современного направления - постмодернизма, обнаруживает большое количество взглядов на это явление, повлекшее как многообразие проявлений, так и разнохарактерность толкований термина. Первое теоретическое обоснование понятие полистилистики получило в докладе "Полистилистические тенденции в современной музыке" А. Шнитке. Определение понятия "полистилистика", которое наметилось в исследовании А. Шнитке, сформировалось в устойчивую форму в дефинициях следующих поколений искусствоведов и современников, вывело данное явление на уровень музыковедческой категории. В научное пространство привлекается ряд смежных понятий, которые по-разному раскрывают стилевые взаимодействия, однако в определенной степени соответствуют категории полистилистики. Осуществленная работа над составлением дефиниций полистилистики и разнообразной терминологии сможет обогатить взгляды ученых на проблемы полистилистики и раскрыть сущность явления с разных позиций.

Ключевые слова: стиль, полистилистика, стилистическая полифония, стилевое моделирования, межкультурные взаимодействия.

The relevance of the research topic. Recently, more and more attention has been paid to the problems of style as an important category of musicology. Style is a multilevel category, interpreted by scholars from different points of view. Musical art of the last decades of the $\mathrm{XX}^{\text {th }}$ and the beginning of the $\mathrm{XXI}^{\mathrm{st}}$ centuries shows a variety of styles and one of the features of stylistic interactions - polystylistics. This phenomenon has become a characteristic feature of postmodernism and a feature of the creative thinking of a contemporary composer. Different views on the problems of stylistic contamination require some generalization, concretization, and ordering.

Analysis of recent research and publications. Polystylistics as a phenomenon has repeatedly been the subject of research in contemporary musicology. Since the 1970s, the term has become widespread in the foreign as well as in the domestic scientific field. A. Schnittke's research positions [21;22] were picked up by subsequent generations of scientists and developed in the works of Yu. Kholopov [19], V. Medushevskiy [16], M. Aranovskiy [2], L. Berezovchuk [3], Ye. Chigareva [20], L. Kazantseva [11], N. Ilichova [9], L. Vorotyntseva [4], and others. Ukrainian musicology also did not stay away from the process of exploring one of the leading trends in contemporary art. The issues of polystylistics are discussed in the investigations of I. Liashenko [15], I. Kokhanyk [12], etc. The phenomenon of stylistic interactions became the object of research in the theses of Yu. Gribinjenko [7], S. Anokhina [1], O. Kuzmenkova [13], and others.

The purpose of the study is to reveal the essence of the category of polystylistics on the basis of musicological research and to characterize the related concepts that correspond to the manifestations of stylistic interactions.

The main presentation of the material. The first theoretical substantiation of the concept of polystylistics was given in the report "Polystylistic Tendencies in Contemporary Music" by A. Schnittke [21], with which he spoke at the International Congress on October 8, 1971. The composer and musicologist, studying the stylistic aspects of the works of composers and composer schools of different directions and nationalities of the twentieth century, concluded that in the modern musiccompositional world the tendency of "conscious use of elements of "alien" style" can be clearly traced [21, 327]. The scientist refers to the practice of various stylistic interactions and stylistic contaminations with the term "polystylistics". A. Schnittke regarded polystylistics as a modern technique of composition, as a "conscious technique" where "the composer preplans the polystylistic effect, whether it is the shock effect of collage collision of musical times, or it is sliding through the phases of musical history, or the most subtle as if accidental allusions" [21, 329]. At the same time, the scientist provides the term and the phenomenon with a broader, generalized interpretation in the form of a "new pluralistic musical consciousness" formed as a result of confrontation "with the terms of conservative and avant-garde academism", creating an alternative to "the purest conventionality - the concept of style as a purely clear phenomenon [21, 327]. Thus, A. Schnittke opposes the polystylistic manifestations and their aesthetic aims to the avant-garde principles of creativity, claiming the legitimacy of "expanding the range of expressive means", integration of "low" 
and "high" styles, "banal" and "sophisticated", "broad musical world", the way of general "democratization of style" [21, 330]. A. Schnittke views polystylistics as a kind of "breakthrough", which "is caused by the tendency of the expansion of musical space inherent in the development of European music" and as a tendency "to increase the organic unity of the form" [21, 329-330]. Thus, the composer outlines the ways for the future development of art, whereas a "new dimension of music" and "a means of artistic expression of the "link of the times"'" the prospects for polystylistics open [Ibid, 331].

The definition of the term "polystylistics", which has already emerged in the study of A. Schnittke, was formed into a more stable form in the definitions of the following generations of art critics and contemporaries, which brought this phenomenon to the level of the musicological category.

M. Aranovskiy is one of the first after A. Schnittke, who studies the phenomenon of polystylistics and treats it as a "special creative concept of individual style", which relies on the "principle of free operation with other styles as elements with established expressiveness" [2, 157159]. The researcher assures that in the process of making music the composer operates with various elements of styles that act as certain characters. The main quality of polystylistic works, in his opinion, is the emergence of stylistic multilayered text, which can be called "metastyle".

Guided by M. Aranovsky's research, where he views polystylistics as part of style theory, there appear a number of works by V. Medushevskiy [16], G. Grigorieva [6], M. Lobanova [14], L. Kazantseva [11] and others. V. Medushevsky characterizes polystylistics as a peculiarity of style system of the second half of the $\mathrm{XX}^{\text {th }}$ century. In its techniques, the researcher sees typical for modern art reflection of "artistic self-reflection of culture" [16, 14]. G. Grigorieva considers polystylistics in a broad and narrow sense. In the broad sense, polystylistics for the researcher is a style of the era, where active style interweaving, style pluralism, style interactions, comparisons, and assimilation are manifested. The narrow meaning of polystylistics is manifested in its definition as "a particular type of compositional technique associated with the inclusion of a quotation plan, a play of styles (allusions) and other methods of deliberate style confrontations" [6, 111]. A. Schnittke and M. Aranovskiy had the same point of view. M. Lobanova, analyzing the factors of origin of different phenomena of artistic creativity, as well as previous researchers, considers polystylistics as one of the stages of formation and development of the style system of art of the $X^{\text {th }}$ century [14]. At the same time, the "Music Encyclopaedic Dictionary" provides one of the first, though not sufficiently perfect, definitions of the term "polystylistics" in Y. Kholopov's interpretation: "Polystylistics $<\ldots .>$ is a deliberate combination of incompatible (or, at least, deeply different and mixed) stylistic elements in one work" [19, 431]. The scholar clearly delineates the concepts of polystylistics from such phenomena as "alien theme in variations", "use of folk melody", "imitation of its style", "instrumentation of works of other composers", "certain types of quotations" and "inconsistency of style" [Ibid]. Among the modern researches devoted to the systematization of scientific sources of information on polystylistics, attention is drawn to an analytical essay by E. Chigareva, that provides a sufficiently complete and specific definition of the term: "Polystylistics is a compositional technique, based on the combination of two or more style models in one work (more often they are personified, in the form of themes-quotations or quasi-quotations, rarely - dispersed in the musical matter) - in a contrasting or complementary ratio" [20, 431]. Newly introduced in a short essay of the researcher is also the theory of polystylistics, where this phenomenon is in dialectical unity with the musical form. E. Chigareva identifies two opposite vectors of interdependence: the processes of polystylistics are subordinate to form and the formations are subordinated to polystylistics. At the same time, the researcher detects several transitional types, which allows "to build a certain conventional classification on the principle of a "spectral serie"" $[20,445]$.

K. Yaskov writes about polystylistics as a method of composer creativity and sees in it an embodiment of the general tendency of the last decades, aimed at "artistic comprehension of the whole varied spectrum of musical layers of the world multicultural space". The researcher defines the method of polystylistics as a system of "theoretical and practical knowledge, skills and abilities of the composer, within which it is possible both to compare and integratively synthesize the characteristic features of the musical language of any national, historical and individual style" [24].

Among the modern definitions of the "polystylistics" term one can single out the definition of S. Anokhina, which is associated with the main cultural meaning of this phenomenon, appearing as "contact with the culture of past eras, space-time reconstruction, appeal to different cultural and historical layers of memory. generating inter- and hypertextuality, quotation, dialogism" $[1,11]$.

Polystylistics, as "a special manifestation of the stylistic activity of contemporary music", which reaches "polysystematic character", is considered by $\mathrm{V}$. Ionov, who characterizes it as the freedom of "stylistic self-dialog of music" and distinguishes "new symbolic functions of music as a language." The researcher, pointing to the priority of linguistic stylistic features, writes: "Polysystematic character exactly indicates that "excessive" stylistic activity becomes the dominance of linguistic qualities of music, when historical styles become the subject of linguistic "play", which leads to their compression, 


\section{Вісник Національної академії керівних кадрів культури і мистецтв № 2'2о20}

stylistic localization, to an aphoristic "citation" that will exclude their transformation into signs substitutes for traditions" [10, 115-116]. G. Gachev wrote about the contiguity and importance of the collision of languages in the last quarter of the $20^{\text {th }}$ century in the paper "National images of the world": "In the junction of languages most acutely is expressed the collision of images of the world and material and spiritual cultures - but the collision that occurs not simply in life, but also on the level of consciousness, the comprehension of life. After all, language is a tree of knowledge. But as branchy and vast it is, as much developed the model of the world lives in the consciousness of the people" [5, 36]. So, polystylistics is also the result of multilingualism.

Within the concept of mastering polystylistics in the music of the $\mathrm{XX}^{\text {th }}$ century in the system of music education, N. Mironova views this phenomenon as "stylistic direction, or as a technique of postmodernism" and considers polystylistics "one of the expressive means by which composers demonstrate the multiplicity of the modern world" $[17,151-152]$. Thus, in our opinion, polystylistics is a combination of specific "style systems", "style levels" in the context of an era of style, individual composer schools, the creativity of a composer or individual work. Beginning from the mid-1970s, polystylistics began to receive new forms of expression and names that correspond to such manifestations. Thus, along with the technical combination of individual styles within a single style system, there appears a desire to subordinate style sources to a single artistic idea. Such a new quality of style, according to G. Grigorieva, is called monostylistics, the essence of which is based on the singularity, uniqueness of the selected type of the synthesized elements characteristic of a single work [6]. The basis of this type of composition is manifested in the conflict-free synthesis of different methods and techniques, which are characteristic of polystylistics as a whole. I. Liashenko proposes the concept of monostylistic synthesis, which means, unlike the position of the previous scientist, the combination of folk and professional principles [15, 82].

Along with the proposed term of polystylistics, A. Schnittke also uses such manifestations that can be denoted by the concepts of "stylistic polyphony" and "stylistic modulation" [21, 330]. However, as the researcher himself admits, there are unknown laws that distinguish between these phenomena.

O. Kuzmenkova names the whole experience of compositional interactions, including polystylistics, with the term "stylistic modeling", defining it as "a compositional technique based on the synthesis and comparison of different stylistic models in different variants within the same work" [13, 13]. In terms of style models, the researcher considers the characteristics of individual, historical, and national style.
According to G. Grigorieva, the term "intercultural style interaction", identical to polystylistics, was used by L. Berezovchuk in the work "Style interactions in D. Shostakovich's works as a way of embodying the conflict" [3]. In his work "National and International in Music" I. Lyashenko applies the concept of national-style diversity, which is similar to polystylistics, which he considers the synthesis of "ethno-local national-specific" and "inter-ethnic factors" [15, 58]. At the same time, the researcher uses a number of other terms that correspond to the meaning of polystylistics: "bistylistics", which is defined as "crossing (synthesis) of two stylistic principles" [15, 81], "polynationality", which he sees as the cause of the formation of different Slavic national-style complexes (West Slavic, East Slavic, South Slavic) [15, 90], "crossbreeding" [15, 91]. S. Savenko, analyzing the problems of individual style in the music of the post-avant-garde, associates the principles of polystylistics with "thinking styles", likening these concepts $[18,100]$. E. Denisov also connects polystylistics with the peculiarities of mental work, saying that this phenomenon is "neither a style nor a technique, but a peculiarity of composer's thinking", [23, 56].

O. Yermolovich points to a certain evolution of the meaning of the term polystylistics and mentions that "having emerged as a type of compositional technique and based on the combination in one work of different stylistic phenomena, using different techniques <...>, it (polystylistics $-Y u$. K.-I.) takes on a different meaning, more capacious, broader, more diverse" $[8,30]$. Polystylistics is considered by the author at the level of "special conception of style", "new logic of style" and as "a method of artistic thinking of the era" $[8,30-31]$. For a deeper understanding of the phenomenon, O. Yermolovich applies the concepts of "polystylistics", "polystyle", "polystylism". The author defines polystylistics as a "'poly"-tendency", which has become an integral feature of "all levels of the organization of artistic creativity of our time, which affects the formation, texture, etc.". Polystyle (many styles, the richness of styles) for a scientist reflects the characteristics of the state of the historical period, reflecting the stylistic heterogeneity of artistic culture. Polystylism is defined by the researcher as ambiguity, heterogeneity of the artistic image in terms of content and form, as well as "a tendency that results in a "style counterpoint"" $[8,31]$. Polystylism is described by $\mathrm{O}$. Yermolovich as an "intellectual quality" inherent in artistic thinking of the late $\mathrm{XIX}^{\text {th }}-\mathrm{XX}^{\text {th }}$ centuries, which is based on" syntheticity, associativity, and multi-style variation" [Ibid]. I. Kokhanyk also speaks about polystylism, polystylistics, and monostyle, pointing out that "the specific character of modern style formation is that these phenomena are rather ambiguous in nature, sometimes uneven, and most importantly, are in a non-linear relationship" [12, 23]. 
Polystylistics, as a method of composer work, is interpreted by L. Vorotyntseva on a "more large-scale level of style", referring to metastyle [4].

The phenomena of polystylistics were manifested not only in music but also in literature, architecture, theatre and cinematography. Thus, in architecture appears the concept of eclecticism, which means similar to polystylistics symbiosis of different stylistic features. This term is beginning to be used in musicology as well. A. Schnittke writes about the "eclectic universalism of contemporary musical consciousness" in the analysis of L. Berio's symphony [22, 90]. In the article "Contemporary Music in the Aspect of the "New Eclecticism"', G. Grigoreva considers eclecticism a certain universality $[6,55]$. K. Stockhausen writes about the concept of "world music" (Weltmusic), where traditions of different peoples are combined: "New "eclectic" styles should in a completely new way expand the world of musical forms and expressive means" [25]. Thus, the term "eclecticism" takes on a new, broader meaning, which brings it to the system level. At the same time, eclecticism acquires the meaning of a general aesthetic category, such as "renaissance", "classicism". It can be predicted that the interaction, the mutual influence of the properties that characterize the polystylistics of different types of art, create a dialectical unity of forms of existence, contributing to the unity of styles. N. Ilichova concisely concludes that "as a way of form and meaning formation, polystylistics penetrates into works of different kinds of art and expresses mentality of the postmodern era" [9, 185-186].

Conclusions. Polystylistics, as a phenomenon of contemporary art and as a category of musicology, has been gaining new scientific interpretations starting from its origin to the present time. The combination of styles, which became the basis for the modern trend - postmodernism, reveals a large number of views on this phenomenon, which has led to both varieties of manifestations and a variety of interpretations of the term. At the same time, a number of related concepts are involved in the scientific space, which reveals style interactions in different ways, but to a certain extent correspond to the category of polystylistics. Thus, the work which was done to arrange the definitions of polystylistics and diverse terminology will be able to enrich the views of scientists on the problems of polystylistics and reveal the essence of the phenomenon from different points of view.

\section{Лimepamypa}

1. Анохина С.В. Полистилистика в музыкальной культуре постмодернизма: автореф. дис. ... канд. культурологии: 24.00.01 Теория и история культуры / Краснодарский государственный университет культуры и искусств. Краснодар, 2009. 22 с.

2. Арановский М. Симфонические искания. Проблема жанра симфонии в советской музыке 1960 1975 годов: Исследовательские очерки. Ленинград: Советский композитор, 1979. $287 \mathrm{c}$.

3. Березовчук Л. Стилевые взаимодействия в творчестве Д. Шостаковича как способ воплощения конфликта. Вопросы теории и эстетики музыки. Вып 15. Ленинград: Музыка, 1977. С.95-119.

4. Воротынцева Л. А. Современные подходы к проблеме полистилистики. Философскокультурологические исследования: электронное научное издание Луганской государственной академии культуры и искусств имени М. Матусовского. Луганск, 2018. № 4. URL: http://fki.lgaki.info/2018/ 10/02/современные-подходы-к-проблеме-полис/ (дата звернення: 03.04.2019).

5. Гачев Г. Национальные образы мира. Москва: Советский писатель, 1988.439 с.

6. Григорьева Г. Стилевые проблемы русской советской музыки второй половины XX века: 50 - 60е годы. Москва: Советский композитор, 1989. 206 с.

7. Грібінєнко Ю. О. Музична полістилістика у світлі теорії інтертекстуальності: автореф. дис. ... канд. мист.: 17.00.03 Музичне мистецтво / Одеська державна музична академія імені А. В. Нежданової. Одеса, 2006. 20 c.

8. Ермолович О. Феномен полистилистики в художественной культуре XX века. Человек. Культура. Общество: Тезисы докладов I Междунар. научн. конф. студентов и аспирантов. (г. Минск, 21-22 мая 2004 г.) / Отв. ред. А. А. Легчилин. Минск: БГУ, 2004. C. 30-32 URL: http://elib.bsu.by/bitstream/ 123456789/46549/1 (дата звернення: 03.04.2019).

9. Ильичёва Н. Полистилистика как феномен художественного творчества XX в. Знание. Понимание. Умение. Москва: Музыка, 2011. Вып. 3. С. 182-186.

10. Ионов В. Стиль в музыке как предмет культурологического исследования. Музичне мистеитво і культура: Науковий вісник ОДМА ім. A. В. Нежданової : [зб. статей / гол. ред. О. В. Сокол]. Одеса: Друкарський дім, 2006. Вип. 7, кн. 1. С. 115-125.

11. Казанцева Л. Полистилистика в музыке: Лекция по курсу "Анализ музыкальных произведений". Казань: Казанская государственная консерватория, 1991. 35 с.

12. Коханик И. Между полистилистикой и метастилем: о стилевых исканиях украинских композиторов на рубеже XX-XXI веков. Світова та вітчизняна музична культура: стилі, школи, персоналії. Київ: Музична Україна, 2012. С. 22-26.

13. Кузьменкова О. А. Стилевое моделирование в творчестве отечественных композиторов 70-90-х годов XX века: Симфоническая и инструментальная музыка : автореферат дис. ... кандидата искусство-ведения: 17.00.02 / Рос. гос. пед. ун-т им. А.И. Герцена. СанктПетербург, 2004. 24 с.

14. Лобанова М. Музыкальный стиль и жанр: история и современность. Москва: Советский композитор, 1990. $312 \mathrm{c.}$

15. Ляшенко I. Національне та інтернаціональне в музиці. Київ: Наукова думка, 1991. 269 с. АН Української РСР, Ін-т мист-ва, фольклору та етнографії ім. М. Т. Рильського. 


\section{Вісник Національної академії керівних кадрів культури і мистецтв № 2'2о20}

16. Медушевский В. К проблеме сущности, эволюции и типологии музыкальных стилей. Музыкальный Современник. Москва: Советский композитор, 1984. Вып. 5. С. 5-17.

17. Миронова Н. Н. Теретико-методологическая концепція освоения полистилистики в музыке XX века в системе музыкльного образования. Преподаватель XXI век. Москва: Московский педагогический государственный университет, 2013. № 3. С. 151-156.

18. Савенко С. Проблема индивидуального стиля в музыке поставангарда. Кризис буржуазной культуры и музыка. Ленинград: Музыка, 1983. Вып. 5. С. 96-112.

19. Холопов Ю. Полистилистика. Музыкальный энциклопедический словарь / Гл. ред. Г. В. Келдыш. Москва: Советская энциклопедия, 1990. С. 431.

20. Чигарёва Е. Полистилистика. Теория современной композиии: учебное пособие / отв. ред. В. С. Ценова. Москва: Музыка, 2005. С. 431-450.

21. Шнитке А. Полистилистические тенденции современной музыки. Холопова B., Чигарева $E$. Альфред Шнитке: Очерк жизни и творчества. Москва: Советский композитор, 1990. С. 327-331.

22. Шнитке А. Третья часть "Симфонии" Л. Берио. Шнитке А. Статьи о музыке / Ред.- сост. А. Ивашкин. Москва: Композитор, 2004. С. 88-91.

23. Шульгин Д. И. Признание Эдисона Денисова (по материалам бесед). Москва: Композитор, 1998. 465 с.

24. Яськов К. Е. Метод полистилистики как системный объект: структура и элементы. Наука в современном мире: материалы V Международной научно-практической конференции (Таганрог, 22 марта 2011 г.) / Под ред. Г. Ф. Гребенщикова. Москва: Издательство «Спутник+», 2011. С. 55-59. URL: http://yaskou.by/nauka/yavlenie-polistilistiki-v-konteksteissledovanij-russkoyazychnogo-muzykovedeniya/ (дата звернення: 06.04. 2019).

25. Stokhausen K. Weltmusic. Music und Bulgung. 1974. №1. URL: http://www.opentextnn.ru/music/ personalia/schtokhauzen/ (Last accessed: 15.04.2019).

\section{References}

1. Anokhina, S. V. (2009). Polystylistics in the Musical Culture of Postmodernism. Extended abstract of candidate's thesis. Krasnodar [in Russian].

2. Aranovskiy, M. (1979). Symphonic Searches. The problem of the symphony genre in Soviet music of 1960-1975: Research essays. Leningrad: Sovetskiy kompozitor [in Russian].

3. Berezovchuk, L. (1977). Style interactions in the works of D. Shostakovich as a way of embodiment of the conflict. Questions of the theory and aesthetics of music. (Issue 15), (pp. 95-119). Leningrad: Muzyka [in Russian].

4. Vorotyntseva, L. A. (2018). Modern Approaches to the Problem of Polystylistics. Philosophical and Cultural Studies: an Electronic Scientific Publication of the Lugansk State Academy of Culture and Arts named after M. Matusovsky. 4. Retrieved from: http://fki. lgaki.info/2018/10/02/современные-подходы-кпроблеме-полис/ [in Ukrainian].

5. Gachev, G. (1988). National Images of the World. Moscow: Sovetskiy pisatel [in Russian].

6. Grigoreva, G. (1989). Style Problems of Russian Soviet Music of the Second Half of the $\mathrm{XX}^{\text {th }}$ century: 5060 years. Moscow: Sovetskiy kompozitor [in Russian].

7. Ghribinjenko, Ju. O. (2006). Musical Polystylistics in the Light of Intertextuality Theory. Extended abstract of candidate's thesis. Odessa [in Ukrainian].

8. Yermolovich, O. (2004). The Phenomenon of Polystylistics in the Artistic Culture of the $\mathrm{XX}^{\text {th }}$ century.
Person. Culture. Society. Retrieved from: http://elib. bsu.by/bitstream/123456789/46549/1 [in Belarus].

9. Ilicheva, N. (2011). Polystylistics as a Phenomenon of $\mathrm{XX}^{\text {th }}$ Century Art. Knowledge. Understanding. Skill. (Vol. 3), (pp. 182-186). Moscow: Muzyka [in Russian].

10. Ionov, V. (2006). Style in Music as a Subject of Culturological Research. O. V. Sokol (Eds.), Musical mystery and culture. (Vol. 7, Book 1), (pp. 115-125) Odesa: Drukarsjkyj dim [in Ukrainian].

11. Kazantseva, L. (1991). Polystylistics in Music: Lecture on the Course "Analysis of Musical Works". Kazan: Kazanskaya gosudarstvennaya konservatoriya [in Russian].

12. Kokhanik, I. (2012). Between Polystylistics and Metastyle: on the Style Searches of Ukrainian Composers at the Turn of the $20^{\text {th }}-21^{\text {st }}$ centuries. World and National Music Culture: Styles, Schools, Personalities. (pp. 22-26). Kyiv: Muzychna Ukrajina [in Ukrainian].

13. Kuzmenkova, O. A. (2004). Style Modeling in the Works of Domestic Composers of the 70-90 of the XX century: Symphonic and Instrumental Music. Extended abstract of candidate's thesis. St. Petersburg [in Russian].

14. Lobanova, M. (1990). Musical Style and Genre: History and Modernity. Moscow: Sovetskiy kompozitor [in Russian].

15. Ljashenko, I. (1991). National and International in Music. Kyiv: Naukova dumka [in Ukrainian].

16. Medushevskiy, V. (1984). On the Problem of the Essence, Evolution and Typology of Musical Styles. Musical Contemporary. (Issue. 5), (pp. 5-17). Moscow: Sovetskiy kompozitor [in Russian].

17. Mironova, N. N. (2013). Theory-methodological Conception of the Development of Polystylistics in the Music of the $\mathrm{XX}^{\mathrm{th}}$ century in the System of Musical Education. Teacher of the XXI century. (Vol. 3), (pp. 151156). Moscow: Moskovskiy pedagogicheskiy gosudarstvennyy universitet [in Russian].

18. Savenko, S. (1983). The Problem of Individual Style in Post-avant-garde Music. The Crisis of Bourgeois Culture and Music. (Issue. 5), (pp. 96-112). Leningrad: Muzyka [in Russian].

19. Kholopov, Yu. (1990). Polystylistics. Musical Encyclopaedic Dictionary. G. V. Keldysh (Ed.). (P. 431). Moscow: Sovetskaya entsiklopediya [in Russian].

20. Chigareva, Ye. (2005). Polystylistics. Theory of Modern Composition. V. S. Tsenova. (pp. 431-450). Moscow: Muzyka [in Russian].

21. Shnittke, A. (1990). Polystylistic Tendencies of Modern Music. Kholopova V., Chigareva Ye. Alfred Schnittke: Essay on Life and Work. (pp. 327-331). Moscow: Sovetskiy kompozitor [in Russian].

22. Shnittke, A. (2004). The Third Part of the "Symphony" L. Berio. Shnittke A. Articles about Music. A. Ivashkin (Ed.). (pp. 88-91). Moscow: Kompozitor [in Russian].

23. Shulgin, D. I. (1998). Recognition of Edison Denisov (based on interviews). Moscow: Kompozitor [in Russian].

24. Yaskov, K. E. (2009). The Method of Polystylistics as a System Object: Structure and Elements. Retrieved from: http://yaskou.by/nauka/yavleniepolistilistiki-v-kontekste-issledovanij-russkoyazychnogomuzykovedeniya/ [in Russian].

25. Stockhausen, K. (1974). World Music. Music and bulge. 1. Retrieved from: http://www.opentextnn.ru/ music/ personalia/ schtokhauzen/ [in German].

Стаття надійшла до редакиії 27.01.2020 Прийнято до друку 29.02.2020 